Article

\title{
A Spatial Information System (SIS) for the Architectural and Cultural Heritage of Sardinia (Italy)
}

\author{
Giuseppina Vacca *(1), Donatella Rita Fiorino and Davide Pili \\ DICAAR, Department of Civil and Environmental Engineering and Architecture, University of Cagliari, \\ P.zza D'Armi, 09123 Cagliari, Italy; donatella.fiorino@unica.it (D.R.F.); ingdavidepili@gmail.com (D.P.) \\ * Correspondence: vaccag@unica.it; Tel.: +39-070-6755436
}

Received: 18 December 2017; Accepted: 1 February 2018; Published: 4 February 2018

\begin{abstract}
The paper presents a spatial information system (SIS) developed in the research project, "Tecniche murarie tradizionali: conoscenza per la conservazione ed il miglioramento prestazionale" (Traditional building techniques: from knowledge to conservation and performance improvement), with the aim of archiving and managing the data derived from the project. The research project has the purpose of studying the building techniques of the 13th-18th centuries in the Sardinia region (Italy) for their knowledge, conservation, and promotion. The research is founded on a multidisciplinary approach involving several specialists integrating their expertise and providing their input to the knowledge of the dimensional, technical constructive, mensiochronological, materials, physical-mechanical, and energy performance features. This multidisciplinary approach is used to define the peculiarities and behavior of the examined structures, including their performance levels, and then direct the interventions toward innovative, mindful, and ethically correct solutions. The management of the huge amount of data produced during the research required the building of a SIS composed of a geodatabase connected to a GIS and a WebGIS through a Web Map Service (WMS). The entire infrastructure is developed and implemented using open source software components, and will make the research data available to the scientific and professional communities, both for further development and for technical uses. As of today, we surveyed and archived more than 500 buildings belonging to the Sardinia region architectural heritage, and classified them into four main macro categories: defensive architectures, religious architectures, residential architectures, and industrial architectures.
\end{abstract}

Keywords: cultural heritage; GIS; WebGIS; SIS; conservation; historical building

\section{Introduction}

In recent decades, the conservation and management of historical and architectural heritage has been assuming a great importance for life in modern society, both from tourist, economic, and cultural viewpoints [1]. This has encouraged the public administration and private companies that have ownership of this heritage to invest great amounts of money and personnel in conservation and usability. The Italian Minister for Cultural Heritage, in his Strategic Plan for the Development of Tourism 2017-2022, stated the importance of promoting the cultural and territorial heritage of Italy in order to ensure a stable management and a sustainable, responsible, and innovative fruition of this heritage [2]. In this context, all of the experts and operators of this sector are called to develop multidisciplinary studies and processes that can significantly contribute to this field, which is now internationally referred to as "Cultural Heritage Documentation". This is an interdisciplinary work where all the specialists involved in the conservation of the architectural heritage contribute by sharing their data and studies on a common IT platform, in order to produce a broader and deeper knowledge of the assets that compose this heritage. This also results from the awareness that only a 
close connection between the disciplines involved in a process of conserving the cultural heritage can allow for a complete knowledge of the assets, and thus an effective work of restoration, conservation, and management of the heritage [3].

The evolution of digital technologies, together with the interdisciplinary approach to the matter of cultural heritage, have also encouraged the design and development of information systems for the storage, management, and quality checking of the data, which, going beyond mere archiving, opened significant scenarios for an active, dynamic, and constructive use of such devices [4]. Thus, it is now acknowledged on a global level that the study of cultural and architectural heritage must follow an interdisciplinary approach and be based on modern digital technologies. Indeed, the use of advanced technology can help experts and researchers in this field find techniques and applications that are able to translate the requirements for registration, knowledge, forecasting, quantification, storage, and the exploitation of cultural heritage, which are constantly changing. However, hyper-specialization, which is an increasingly required professional trait, risks alienating those who study the complexity of real objects, by fragmenting them into their smaller components [5].

This multidisciplinary approach, while contributing to the knowledge of the cultural heritage, has also led to a considerable increase in the amount of data involved. Architects, historians, restorers, structural engineers, energy engineers, and geomatics experts, each by their specificities, have to contribute to the historical, metrical dimensional, structural, material, and energy performance knowledge of the buildings, by providing a great quantity of data, which must be managed and integrated [6].

Until some years ago, the management and storage of the data regarding the cultural heritage was provided by databases that were neither interoperable nor accessible by users outside of the agencies that owned the heritage. With the advent of information technology (IT), new tools have also been created for the management of such data from a spatial point of view. This is referred to as a spatial information system (SIS), which is a virtual space where each kind of information, archived in a database, can refer to a specific point in a known spatial reference system [3]. Since the 1990s, the SIS has been seen as the ideal tool for the management and study of cultural heritage. Many of the agencies that deal with cultural heritage have promoted the design and development of such systems as a natural evolution of the traditional databases. This trend is also justified by cultural heritage being composed of assets (buildings, archaeological sites, etc.) that can be spatially geolocated, either by the ease of access to the SIS platform-even for non-expert users-the economic strategy that is the basis for the promotion of cultural heritage worldwide, or finally by the necessity of using modern media in order to disseminate the results of the studies on cultural heritage [3].

Turning to contents, themes, and the related organization of the data, a general evolution of cultural heritage application schema for data management is also registered, in terms of the definition of international standard and vocabularies, such as the Italian Sistema Informativo Generale del CatalogoSIGEC [7], the International Committee for Documentation (CIDOC) [8] from the International Council Of Museums (ICOM) [9], the Spanish Language for the Description of Architectural Elements-L DEA[10], the English MIDAS Heritage [11], or others [12-17].

The solutions based on SIS are numerous, and range from database management systems (DBMS) to geographic information systems (GIS) to WebGIS or Internet GIS; the type used depends on the type of services to be provided to users, the complexity of the infrastructure, and the quantity of data to be managed.

In this field of study, geographic information technology can offer an important contribution, as well as share findings on the Internet for greater diffusion among the users involved.

Whatever system is chosen to manage and share geospatial data on the Web or the wider Internet, it must have the objective of handling and archiving in a satisfactory way the data that is needed in order to have a complete knowledge and understanding of the cultural heritage that is the object of the study [18-22]. 
The geographic information systems have been developed to create relationships between data, analyze spatial information recorded in a database, and manage heritage. Many types of data can be managed in a GIS-not only geospatial or geolocalized data, but also historical, architectural, material, and other data [23] — and it is very important to share these data on the Web through a WebGIS. In addition, the relatively recent emergence of WebGIS functionality has modified the traditional way of using GIS as a database mapping and spatial analytical tool [24,25].

Many works developed in recent years have proven that applying such technologies to the architectural and archaeological heritage was of utmost importance in the development of the interested assets, especially in the planning of their restoration and conservation [26]. In Deidda [27] GIS is used for the management and conservation of the 16th-18th century coastal defense system. In "The use of GIS technology in cultural heritage" [28], Petrescu presents an overview on the use of GIS and WebGIS for cultural heritage around the world. The works in Brovelli, D'Urso, Grossi and Deidda [29-32] are a review of WebGIS applications developed in the field of archaeology and cultural heritage, while Costamagna [33] presents a three-dimensional (3D) GIS study for cultural heritage.

In this paper, we present a spatial information system (SIS) for the architectural and cultural heritage of Sardinia (Italy) built between the 13th-19th century. This is part of the Italian research project called "Tecniche murarie tradizionali: conoscenza per la conservazione ed il miglioramento prestazionale" (Traditional building techniques: from knowledge to conservation and performance improvement), which aims to survey, date, and characterize in technical and energy performance terms the construction techniques of the historical architecture in Sardinia between the 13th-19th century. The research project has a time span of three years, and will conclude in September 2018. This architectural heritage is vast and heterogeneous in typology and function, and features a profound stratification of transformations that have occurred over time. It involves several architectural categories: the Giudicati defensive system (13th-14th century); the coastal towers (15th-17th century); the Piedmontese forts and strongholds (18th-19th century); the city walls (13th-18th century); and the barracks (19th century). The research has produced a great amount of data of different types and characteristics, coming from specialists of various disciplines.

The SIS implemented consists of a geodatabase connected to a GIS and a WebGIS through a Web Map Service (WMS). The entire infrastructure is developed and implemented using open source software components, and will make the research data available to the scientific and professional communities, both for further development and for technical uses.

\section{Materials and Methods}

The research concerned the design and development, using open source tools and components, of a spatial information system (SIS) composed by a geodatabase, a GIS, and a WebGIS. The objective was to survey, store, and manage the great amount of data about the 13th-19th century architectural heritage of Sardinia. The research is founded on a multidisciplinary approach involving several specialists integrating their expertise and providing their input to the knowledge of the dimensional, technical constructive, mensiochronological, materials, physical-mechanical, and energy performance features, in order to define the peculiarities and behavior of the examined structures, their performance levels, and then direct the interventions toward innovative, mindful, and ethically correct solutions.

The management of the huge amount of data produced during the research required the design and implementation of a system for archiving and relating the data, while respecting the stratigraphic approach adopted by the research and maintaining the link between the information and the territory, such as to allow the cross-reading of the geographical distribution and the themes in both synchronic and diachronic ways. Through the selective extrapolation of the data, which can be interrogated in single or aggregate form, the mosaic of knowledge thus constructed is able to answer flexible synthetic queries, responding to the different aspects of the investigated phenomena. Such a tool has made possible a concrete and effective transdisciplinarity of research, as it has allowed overcoming the 
boundaries of traditional scientific sectors, and encouraged contamination through the synergistic collaboration between the numerous specialists involved.

All of the data acquired in the distinct steps of the research and stored in the geodatabase have been made accessible to the users via the Web, by building a WebGIS according to the standards of the Open Geospatial Consortium (OGC) [34], the specifications of the Regione Sardegna (local autonomous government of Sardinia) [35], and the CISIS (Italian Inter-regional Center for GIS and Statistical Services) [36], which in turn are based in the Infrastructure for Spatial Information in Europe (INSPIRE) [37] directive specifications.

The geodatabase is built in PostgreSQL [38] and its spatial extension PostGIS [39], which allows storing and managing feature geometries and spatial data. The data input is performed via a form built in HTML and PHP. The database is accessed in Quantum GIS (QGIS) [40], and the WebGIS was built using the Leaflet Javascript [41] open libraries. The Geodatabase is published on the WWW through an Open Geospatial Consortium (OGC) Web Map Service (WMS) provided by Geoserver [42]. Figure 1 shows the infrastructure architecture.

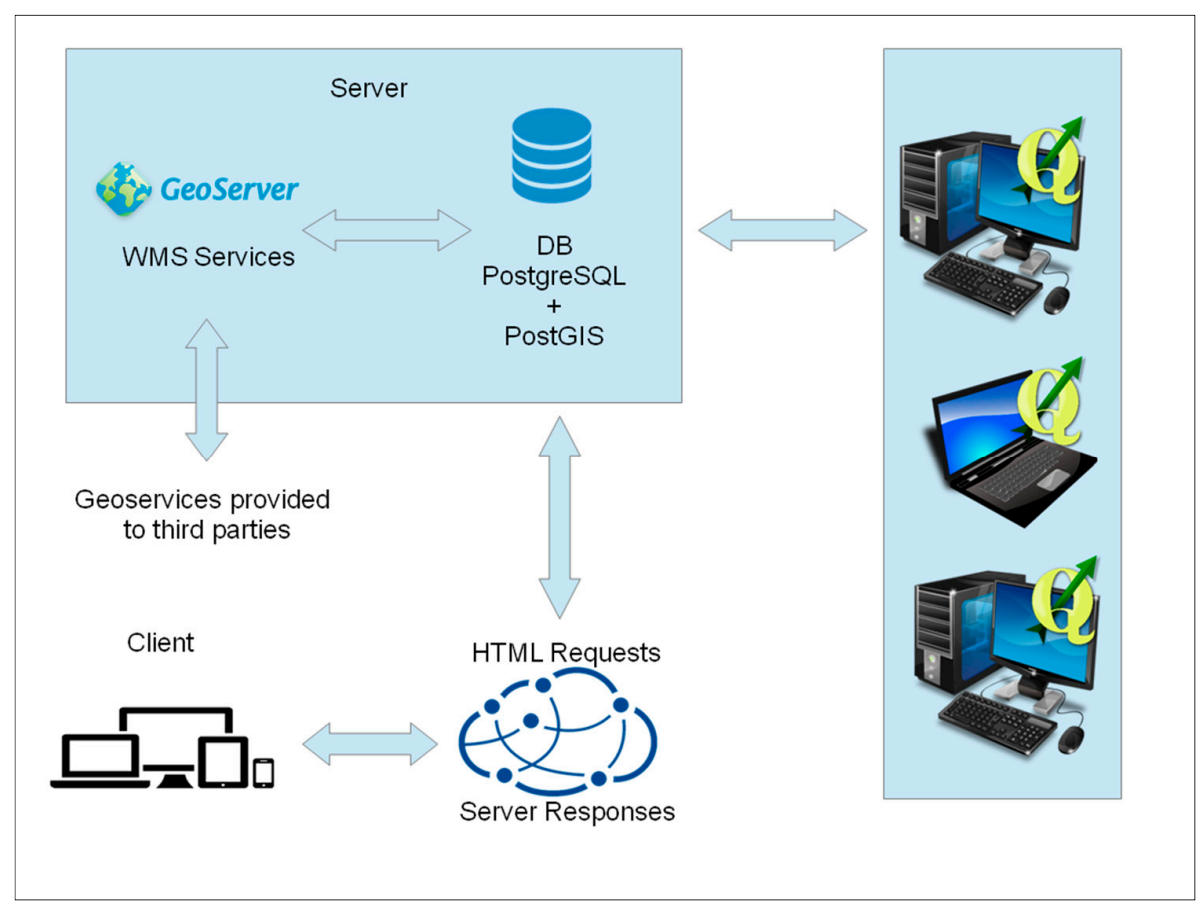

Figure 1. Spatial Information System Infrastructure.

The following paragraphs will describe the structure of the data and the implementation of the geodatabase, GIS, and WebGIS. In order to make the aims and results clear, the description quotes-among the many possible examples-the implementation of the system for a specific case study: the S. Ignazio Fort, an impressive Piedmontese defensive structure that was built at the end of the XVIII century in the city of Cagliari (Sardinia, Italy), and is now in a state of ruin.

The SIS infrastructure developed can be viewed at the link http:/ / abanni.unica.it/wgis_unica/.

\subsection{The Data Structure}

In Italy over the past 30 years, many open source and internet-based information systems have been designed. The first purpose was the cataloguing of national monuments, but quickly the problem shifted to the management of information relating not only to cataloguing, but also to the management of cultural heritage in general—environmental, architectural, historical, artistic, library, archival, and so on-and the documentation of restoration sites. However, different cabinets realized each system, all of which have specific fields of application, and Italy has never been able to 
neatly connect the complex and heterogeneous information necessary to the complete knowledge of a historical architecture. Since 2004, the Central Institute for Catalogue and Documentation (ICCD) of the Italian Ministry for Cultural Heritage and Tourism (MiBACT) has developed and implemented a general catalogue of the archaeological, architectural, historical, artistic, and ethnoanthropological national heritage. The SIGEC/Web system was designed with the aim of optimizing the processes connected to the cataloguing of cultural heritage, guaranteeing data quality and their conformity with national standards through specific procedures in order to exchange data among different cultural institutions [43]. This informative system focuses on Italian needs, and even if it follows the INSPIRE directive, it has its own structure, criteria, and set of vocabularies designed for Italian monuments and laws for protection, which are quite different from the already quoted international experiences.

This national standard had been the base structure for the design of the geodatabase used in this research. However, the final database goes beyond this codified system, according to an innovative stratigraphic approach that, on the one hand, allows descriptions of physically and chronologically stratified buildings, and, on the other hand produces a multilayered knowledge based on the continuous and updatable addition of information for the construction of a complex mosaic of knowledge.

The database has been structured following a hierarchical organization of the data, which is generally divided into two categories: descriptive data and coded values. The latter in particular, through the definition of a complex set of keywords, determines the high level of automation reached by the system regarding the analysis, comparison, and synthesis operations. The essential role of the geodatabase in the research program, in fact, was not only to store a great amount of detailed information in a systematized way, but also and above all to build a framework of relationships between the heterogeneous data, in order to organize complex, ordered, and overlaid thematic views. All of this started from a great number of samples selected without special criteria and distributed on a geographic area as vast as the whole Sardinia region. The comparative analysis of similar data has guided the definition of disciplinary themes and their scientific variations. Still, in order to overcome the partial vision that is intrinsic in the concept of "theme", and achieve an interpretation of complex phenomena, the geodatabase by design can be queried across multiple themes by using the quoted vocabularies. Specifically, the definition of the vocabularies implements the rationalization of the system and the terms used in the database, but it also presents a critical issue, because it must answer at the same time to the transdisciplinary approach, the interoperability principle, and the diversity of the architectural contexts. These are very different from each other in terms of type, function, construction technique, and date of building, which are all factors that also influenced the depth and quality of the data. For these reasons, a great effort was made in order to respect national and international standards, technical terminology, and at the same time, adapt them to local requirements following a general criteria of 'inclusivity'.

In order to address these issues, the design followed a modular and flexible model that was easy to implement both in structure and content (either for integration or correction), and improved step by step as the study advanced. This flexibility also made the database able to be further improved in the future to deal with other possible themes.

The modularity passes through the main structure of the data, which was conceived with two levels of depth: the "unità architettonica" (architectural unit) record contains the territorial census of the assets according to an anagraphical-descriptive layout, which collects the foremost historical and architectural features of each asset. Several sub-records are associated to the architectural unit, including the geospatial location as well as the "strutture" (structures), "infisso" (fixture), and "campione murario" (masonry sample) sub-records, which describe the specific technological features of the construction elements of the architectural unit from formal, dimensional, material, structural, and energy efficient points of view.

The system was designed for cross-checking the interdisciplinary data stored in all of the modules. The most interesting result of this possibility lays in the potential of obtaining a critical selection 
(by the queries) of masonry typologies in relation to a specific chronological range, contributing to the definition of local mensiochronologies and chronotypologies.

Structural and energetic aspects open the database towards other, even disciplines, but they seem to be particularly relevant for the creation of a basic structured literature on important parameters that are quite decisive in the sustainable restoration and reuse projects of historical sites. In this way, the system also inclines experts from different backgrounds towards unexplored fields, widening the research horizon on cultural heritage.

The Architectural Unit macro-category contains the data pertaining to the name, location (with georeferencing), function, cultural dating, and chronological dating, legal status, restrictions, stratigraphy, and conservation, including all of the previous restorations. Specifically, it is organized in these sections: code, object, geographic/administrative location, chronological location, cultural definition, legal status and restrictions, usage, stratigraphy, conservation state, accessibility and view, documents and sources.

Table 1 shows the data types contained in the Architectural Unit record.

Table 1. Architectural Unit Data.

\begin{tabular}{|c|c|c|}
\hline Level I & Type & Descrizione Del Dato \\
\hline \multirow{11}{*}{$\begin{array}{l}\text { UNITA' }^{\prime} \\
\text { ARCHITETTONICA } \\
\text { (Architectural Unit) }\end{array}$} & $\begin{array}{l}\text { Codice } \\
\text { (Code) }\end{array}$ & $\begin{array}{l}\text { Identifies the asset univocally, allowing the database to } \\
\text { interoperate with the MiBACT (Ministry of Cultural } \\
\text { Heritage and Tourism) catalogue systems [44]. }\end{array}$ \\
\hline & $\begin{array}{l}\text { Oggetto } \\
\text { (Object) }\end{array}$ & $\begin{array}{l}\text { Contains the name and typology of the asset, the } \\
\text { morphological qualifiers, a brief description, and a } \\
\text { graphical representation. }\end{array}$ \\
\hline & $\begin{array}{l}\text { Localizzazione } \\
\text { (Location) }\end{array}$ & The geographic coordinates of the architectural unit. \\
\hline & $\begin{array}{l}\text { Definizione cronologica } \\
\text { (Chronological location) }\end{array}$ & $\begin{array}{l}\text { Information about the construction date and } \\
\text { the customers. }\end{array}$ \\
\hline & $\begin{array}{l}\text { Definizione culturale } \\
\text { (Cultural definition) }\end{array}$ & Information about the asset in the cultural sphere. \\
\hline & $\begin{array}{l}\text { Condizione giuridica e vincoli } \\
\text { (Legal status and restrictions) }\end{array}$ & $\begin{array}{l}\text { Information about the legal status of the asset and any } \\
\text { legal restrictions, if present. }\end{array}$ \\
\hline & $\begin{array}{l}\text { Utilizzazioni } \\
\text { (Usage) }\end{array}$ & Information about both the original and current usage. \\
\hline & $\begin{array}{l}\text { Stratigrafia } \\
\text { (Stratigraphy) }\end{array}$ & $\begin{array}{l}\text { Data describing the construction phases and the } \\
\text { "transformation level" of the object. }\end{array}$ \\
\hline & $\begin{array}{c}\text { Conservazione } \\
\text { (Conservation state) }\end{array}$ & $\begin{array}{l}\text { Describes the conservation state, the seriousness of } \\
\text { (possible) issues, and the level of urgency of a possible } \\
\text { intervention. The values are coded according to the } \\
\text { ones in the National Risk Assessment Map [45]. }\end{array}$ \\
\hline & $\begin{array}{l}\text { Accessibilità e panoramicità } \\
\text { (Accessibility and view) }\end{array}$ & Describes the accessibility of the architectural unit. \\
\hline & $\begin{array}{l}\text { Fonti e documenti di riferimento } \\
\text { (Sources and reference documents) }\end{array}$ & $\begin{array}{l}\text { Further information may be supplied by uploading } \\
\text { documents or other files. }\end{array}$ \\
\hline
\end{tabular}

Each Architectural Unit is linked to the "second level" or "detail" records describing the construction elements: structures, fixtures, and masonry samples. These data, and especially the masonry samples, are of fundamental importance for the research: in fact, one of the main goals was to extract a chronological scale from the masonry samples of historically dated buildings, in order to date other buildings of a similar age.

The Structures category contains the data pertaining to the distinct structures that form the architectural unit, in particular the typology of the structure (covers, walls, slabs), the static type (load-bearing or not), the constriction technique, and the energy efficiency. 
The Fixtures category contains the data pertaining to the architectural unit's window fixtures, including their dimensions, materials, and overall energy transmittance.

The Masonry Sample category contains the data pertaining to the construction elements of the architectural unit, in particular their position, chronology, survey, restitution, wall structure, materials used (stone, cement, brick), and examinations performed.

Table 2 shows the data included in the Structure, Fixtures, and Masonry Sample records.

Table 2. Structure, Fixture, and Masonry Sample Data.

\begin{tabular}{|c|c|c|}
\hline Livello II & Tipologia & Descrizione Del Dato \\
\hline \multirow[t]{2}{*}{ Struttura (Structure) } & $\begin{array}{c}\text { Dati generali } \\
\text { (General information) }\end{array}$ & $\begin{array}{l}\text {-ID of the masonry sample } \\
\text {-Position of the sample } \\
\text {-Type of structure } \\
\text {-Qualification } \\
\text {-Static Qualification } \\
\text {-Building technique } \\
\text {-Description }\end{array}$ \\
\hline & $\begin{array}{l}\text { Prestazioni energetica } \\
\text { (Energy efficiency) }\end{array}$ & $\begin{array}{l}\text { Information about the stable and periodic } \\
\text { transmittance, phase shift, and attenuation. }\end{array}$ \\
\hline Infissi (Fixtures) & $\begin{array}{c}\text { Dati generali } \\
\text { (General information) }\end{array}$ & $\begin{array}{l}\text { Information about the fixture type, including its } \\
\text { material and size, and its overall thermal } \\
\text { transmittance. }\end{array}$ \\
\hline \multirow{7}{*}{$\begin{array}{l}\text { Campione Murario } \\
\text { (Masonry Sample) }\end{array}$} & $\begin{array}{c}\text { Dati generali } \\
\text { (General information) }\end{array}$ & $\begin{array}{l}\text { Information about the type and dating of the } \\
\text { masonry sample. }\end{array}$ \\
\hline & $\begin{array}{l}\text { Rilievo e restituzione grafica } \\
\text { (Survey and graphic rendering) }\end{array}$ & $\begin{array}{l}\text { External files describing the surveying of the } \\
\text { masonry sample. }\end{array}$ \\
\hline & $\begin{array}{l}\text { Apparecchiatura } \\
\text { (Brickwork) }\end{array}$ & Information about the brickwork and brick laying. \\
\hline & $\begin{array}{l}\text { Sezione muraria } \\
\text { (Wall section) }\end{array}$ & $\begin{array}{l}\text { Composition and dimensions of the wall section. } \\
\text { Transmittance information. }\end{array}$ \\
\hline & $\begin{array}{l}\text { Lapideo } \\
\text { (Stone) }\end{array}$ & $\begin{array}{l}\text { Type, size, and energy parameters of the } \\
\text { stone elements. }\end{array}$ \\
\hline & $\begin{array}{l}\text { Laterizio } \\
\text { (Brick) }\end{array}$ & $\begin{array}{l}\text { Type, size, and energy parameters of the } \\
\text { brick elements. }\end{array}$ \\
\hline & $\begin{array}{c}\text { Malta } \\
\text { (Mortar) }\end{array}$ & Type, size, and energy parameters of the mortar. \\
\hline
\end{tabular}

\subsection{GeoDatabase Design and Implementation}

The database was designed and implemented using PostgreSQL, a relational DBMS distributed under a Berkeley Software Distribution (BSD) license. The spatial functions of the database were provided by the PostGIS extension, which is distributed under a GNU General Public License (GNU-GPL). This extension turns the DBMS into a Geodatabase by adding functions and data types that can manage geometries and reference systems. Data queries are performed using SQL, the standard language for data extraction in relational databases. SQL is used to create and edit database schemas, as well as input and edit data, in addition to querying.

The management of the database was done using the pgAdmin [46] tool graphical interface. The database is structured in schemas and tables (Figure 2). Each schema contains multiple tables, in order to organize the tables into cohesive themes.

The schemas created in the DB are "decodifica", "campione_murario", "infisso", "struttura", and "unità_architettonica". Each schema contains the tables pertaining to a single input form. The "decodifica" scheme contains the tables of the domains used in the input forms, such as the municipalities and provinces of the Sardinia region. Some fields of the input forms have closed 
dictionaries in order to prevent misspellings and variant spellings, which would make queries impossible. The forms were written in the Italian language.

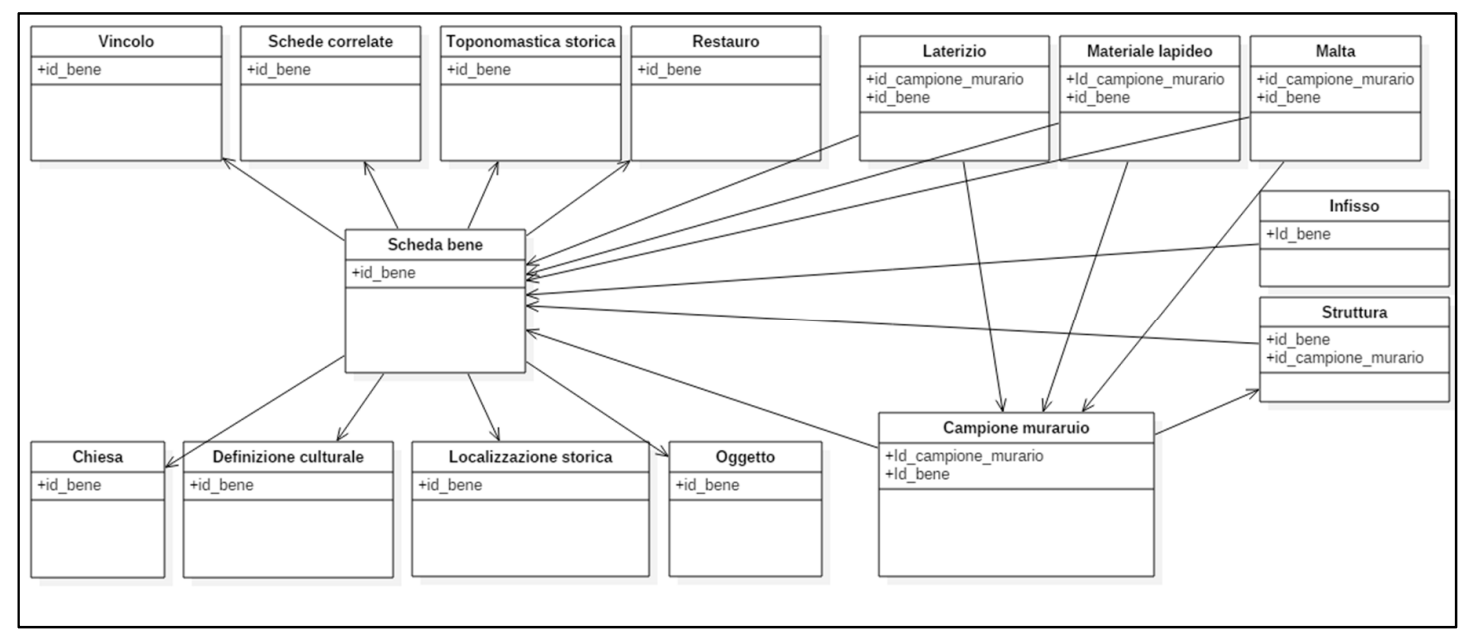

Figure 2. Geodatabase Structure.

The users can input and edit data through the forms created for the applications (Figures 3 and 4). The input form was implemented in PHP and HTML5 using a free template from Bootstrap [47], which is a repository of free tools for creating web sites and applications. The graphical appearance is defined in Cascading Style Sheets (CSS), and Javascript [48] was used to implement navigation and some controls.

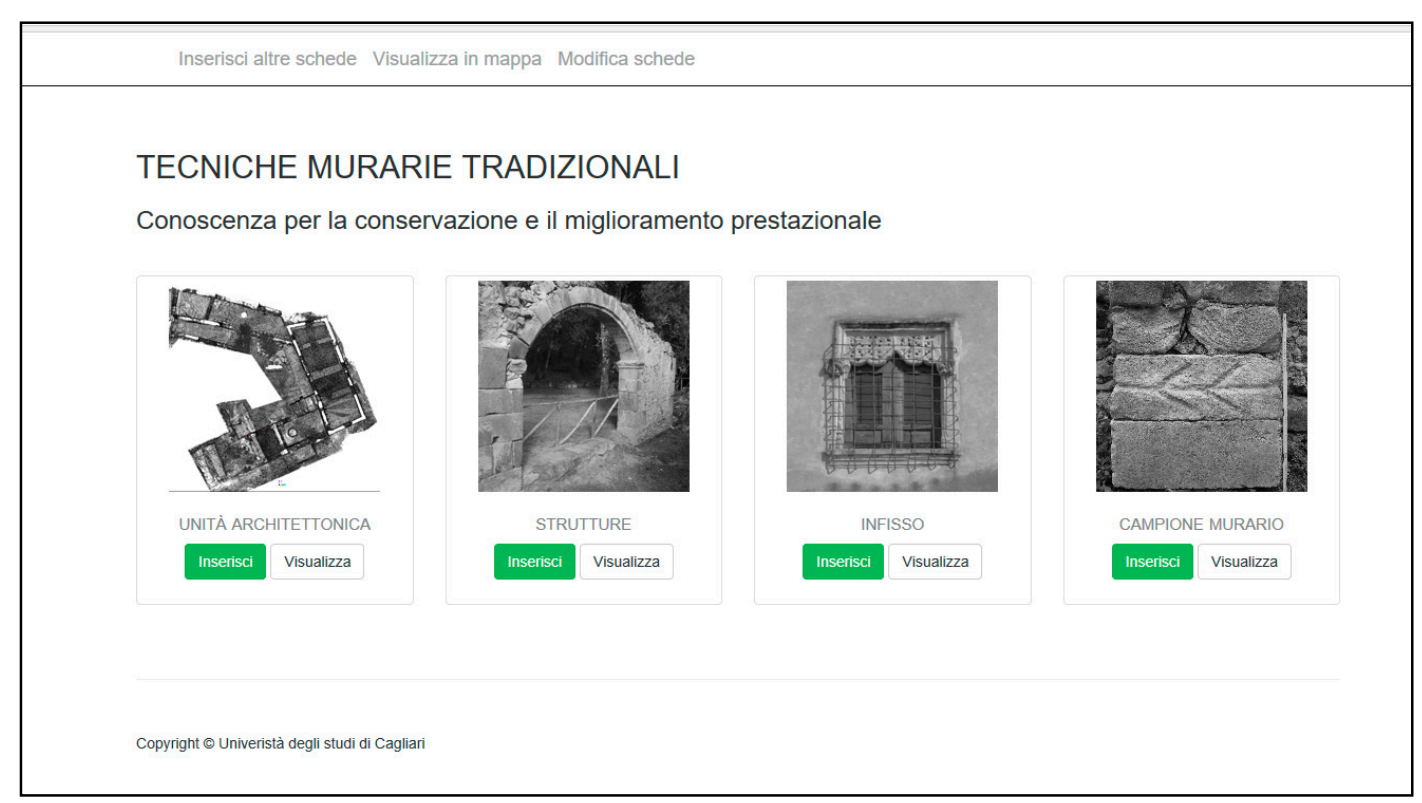

Figure 3. The Geodatabase Start Page. 


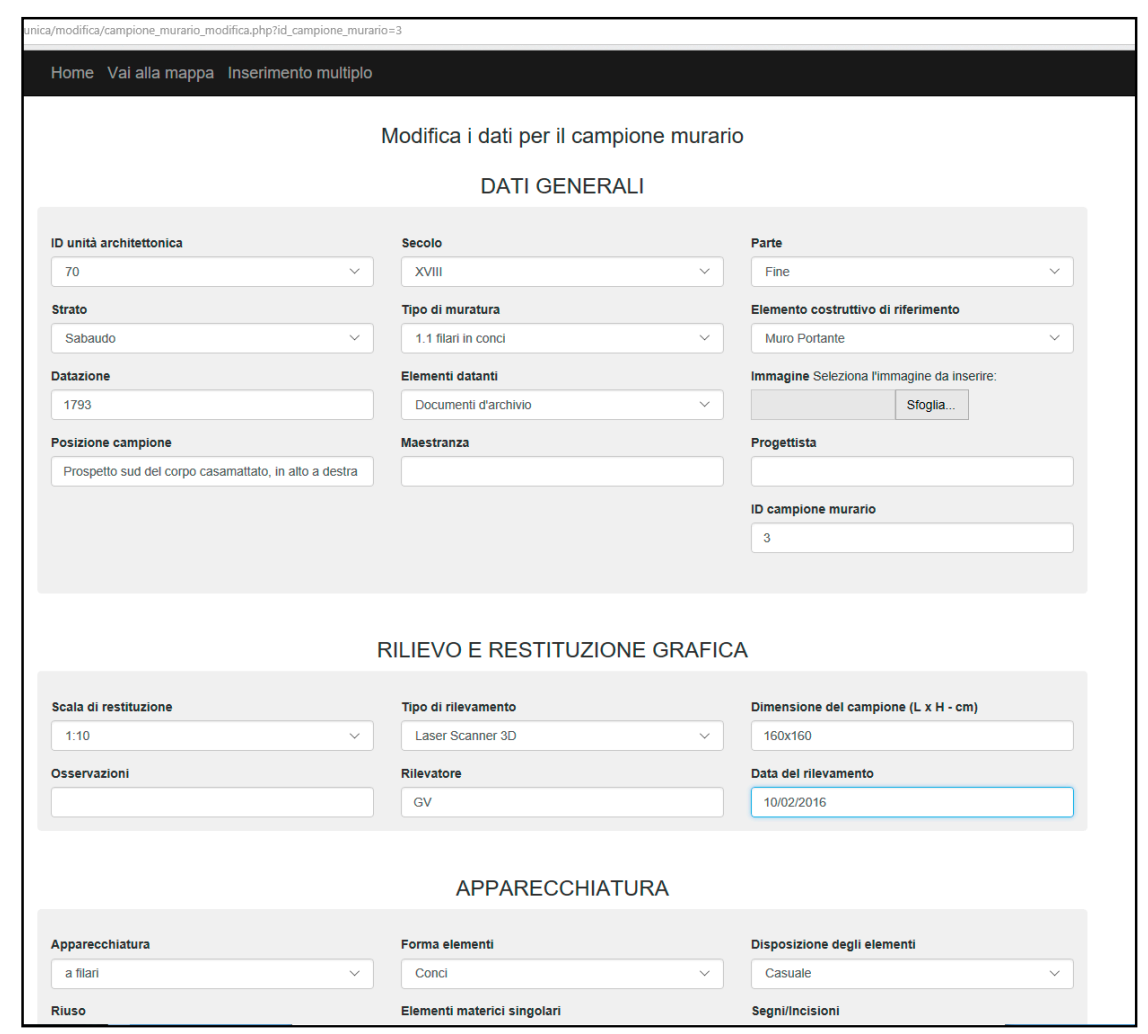

Figure 4. The Example of the Masonry Sample Input Form (S. Ignazio Fort).

\subsection{WEBGIS Design and Implementation}

The WebGIS was built using the Leaflet Javascript open libraries, which allow creating map sites with background maps and navigation, input, and query tools. This too uses an interaction of HTML, Javascript, PHP, and SQL code. The map data published in WebGIS is provided by Geoserver, which in turn extracts the project data from the PostgreSQL database.

The choice to use the OGC geoservices derives from the need to design the interface using only interoperable and open-source software. The Open Geospatial Consortium (OGC) is an international organization that defines standards and technical specifications for localization and geospatial services. The OGC consists of over 280 members (governments, companies, universities), and has the purpose of developing and implementing open and extensible standards for geographical data, and their interchange and distribution. The specifications defined by the OGC are public and freely available.

The OGC maintains more than 30 standards, including:

- WMS-Web Map Service

- WFS-Web Feature Service

- WCS-Web Coverage Service

- GML-Geography Markup Language

The research project requires the interoperability of the data collected in the research, and the ability for the involved agencies and companies to retrieve the data and publish it on their own portals. In particular, the project involves the development of WMS to be made available for the Sardinia Autonomous Region and the Ministry for Cultural Heritage and Tourism.

The WMS service is created automatically, and follows any modification of the database tables in real time. The corresponding Geoserver URL is then embedded in the HTML code of the WebGIS in order for the data to be shown on the map.

The WMS service is displayed using the L.tileLayer.wms module from the Leaflet library. The following code listing is an example of its use in the project. 
var wms =

L.tileLayer.wms('http:/ / abanni.unica.it:8080/geoserver/LR7/wms?' , \{

maxZoom: 22,

minZoom: 0,

layers: 'LR7:xxnome_tabellaxx',

format: 'image/png',

zIndex: 1000,

transparent: true

\}).addTo(map);

In the WMS provided by Geoserver, each architectural unit in the geodatabase is rendered with a point geometry primitive. The WebGIS also connects to some base maps provided by the Sardinia region geoservices [49,50] (specifically, the 2010 and 2013 orthophoto mosaics), and some layers from the regional Multi-Precision GeoDatabase that were meaningful for this project: "Manufatti di culto" (Religious items), "Manufatti edilizi" (Building items), "Edificio-Unità immobiliare" (Building-Construction Unit), and "Unità Volumetrica" (Building-Volume Unit). Finally, the WebGIS allows for use of the Open Street Map dataset as a base map. The orthophotos and Open Street Map can be alternately displayed using the layer control (Figure 5). The datum used in the WebGIS and the entire infrastructure is ETRF2000 [51].

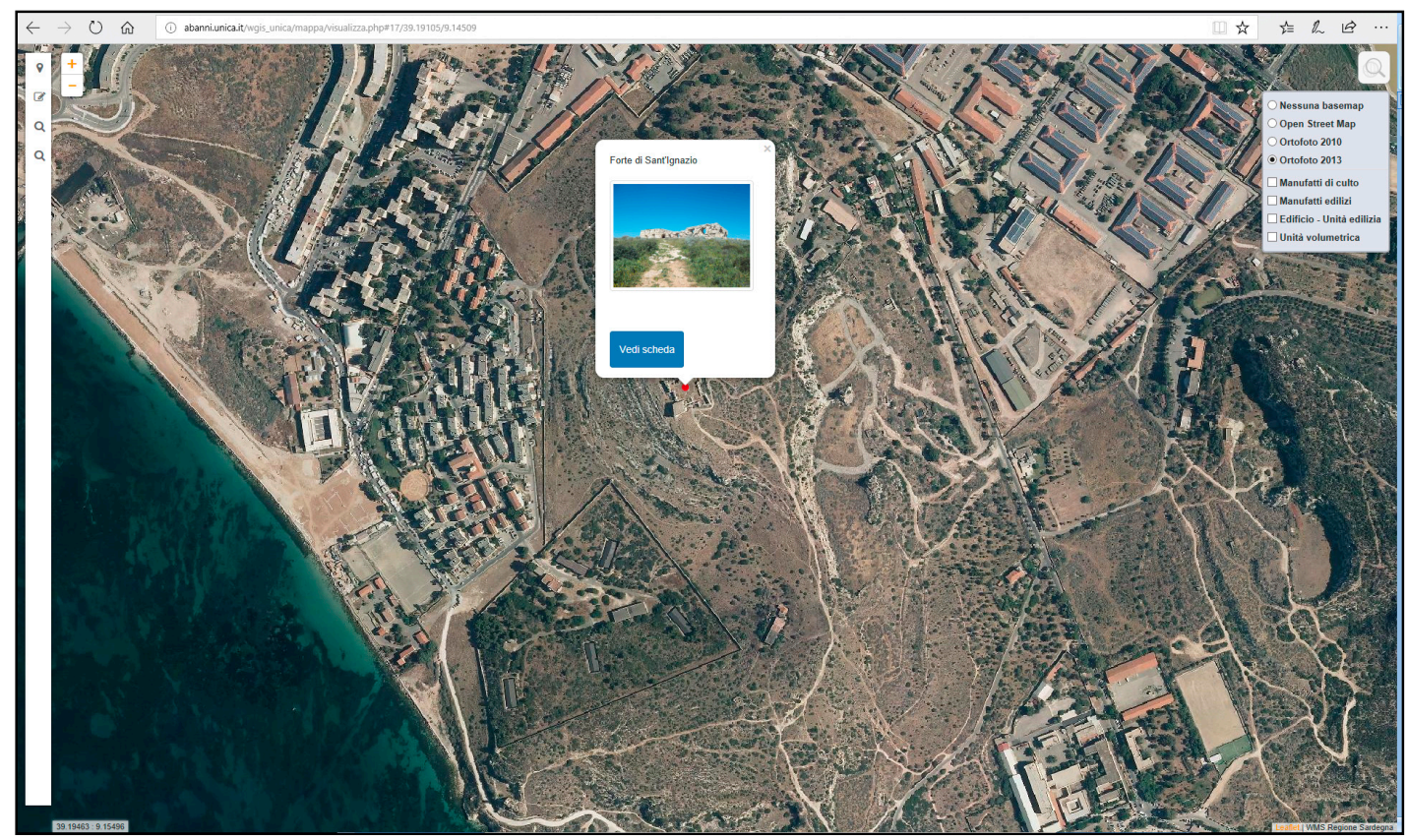

Figure 5. The WebGIS and the Layer Control for the Base Maps (S. Ignazio Fort).

WebGIS was designed to leave the most possible screen space to the map itself, limiting the navigation tools to the strict minimum. It also includes a list of visible layers and a search tool for querying the WMS services, as shown in Figure 6.

Another functionality of WebGIS is the updating of the geodatabase using an entry form that allows geolocating the architectural unit either by placing it on the map or by providing its ETRF2000 geographic coordinates, as shown in Figure 7. This operation activates a trigger that updates the geometry field of the architectural unit table.

A trigger is a construct that signals the database to execute a particular function every time a certain operation is performed. In this case, the trigger is activated when a new record is input using the asset form, and compiles the geometry field using the coordinates submitted in the form. 
After the input of the coordinates, the input forms will be filled in with all of the data related to the architectural unit and its components (structures, window fixtures, masonry samples). At the end of the input, the relative record in the geodatabase is populated, and the Geoserver updates the WMS so as to align the geometrical data published in the map with the content of the Geodatabase.

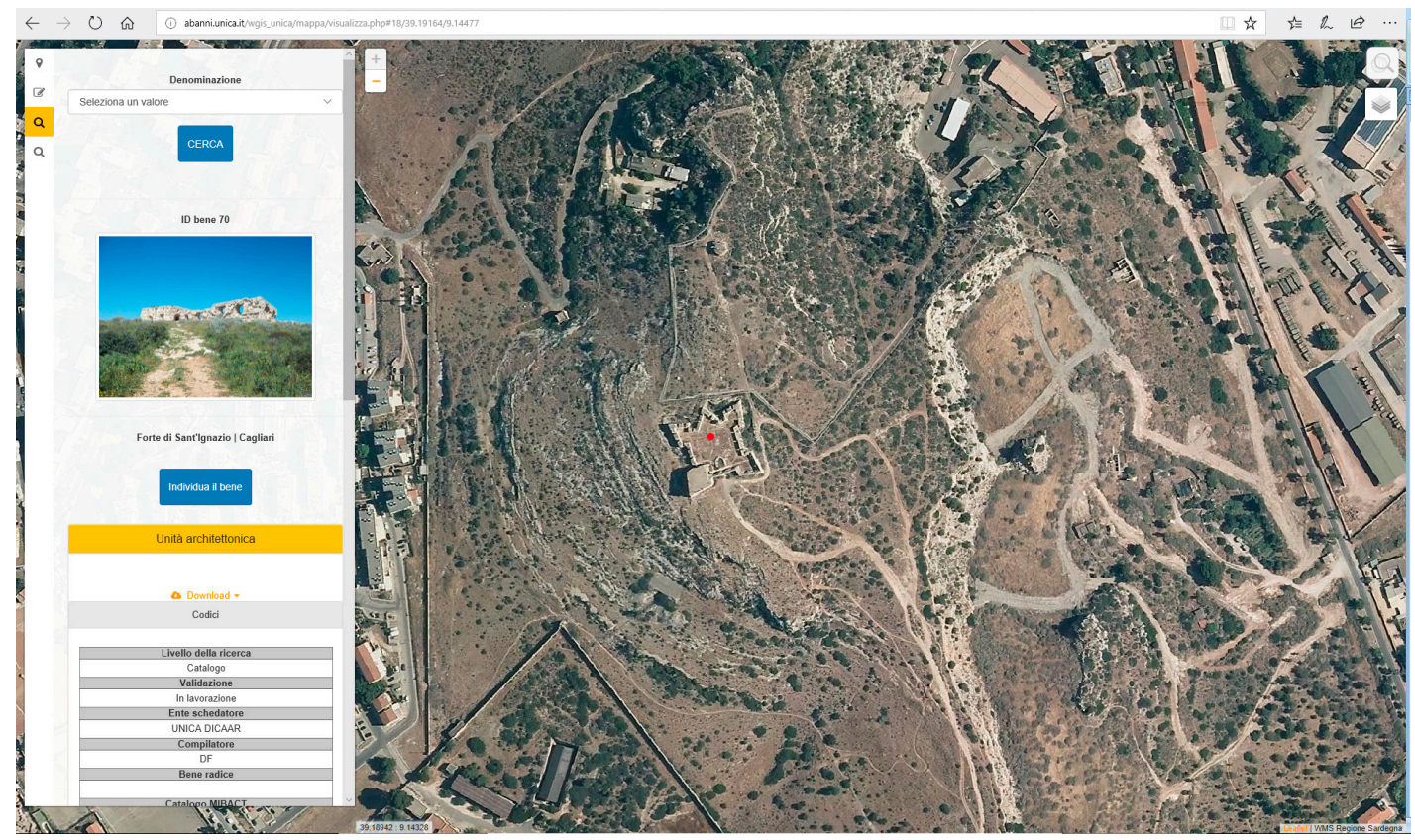

Figure 6. The Search Tool (S. Ignazio Fort).

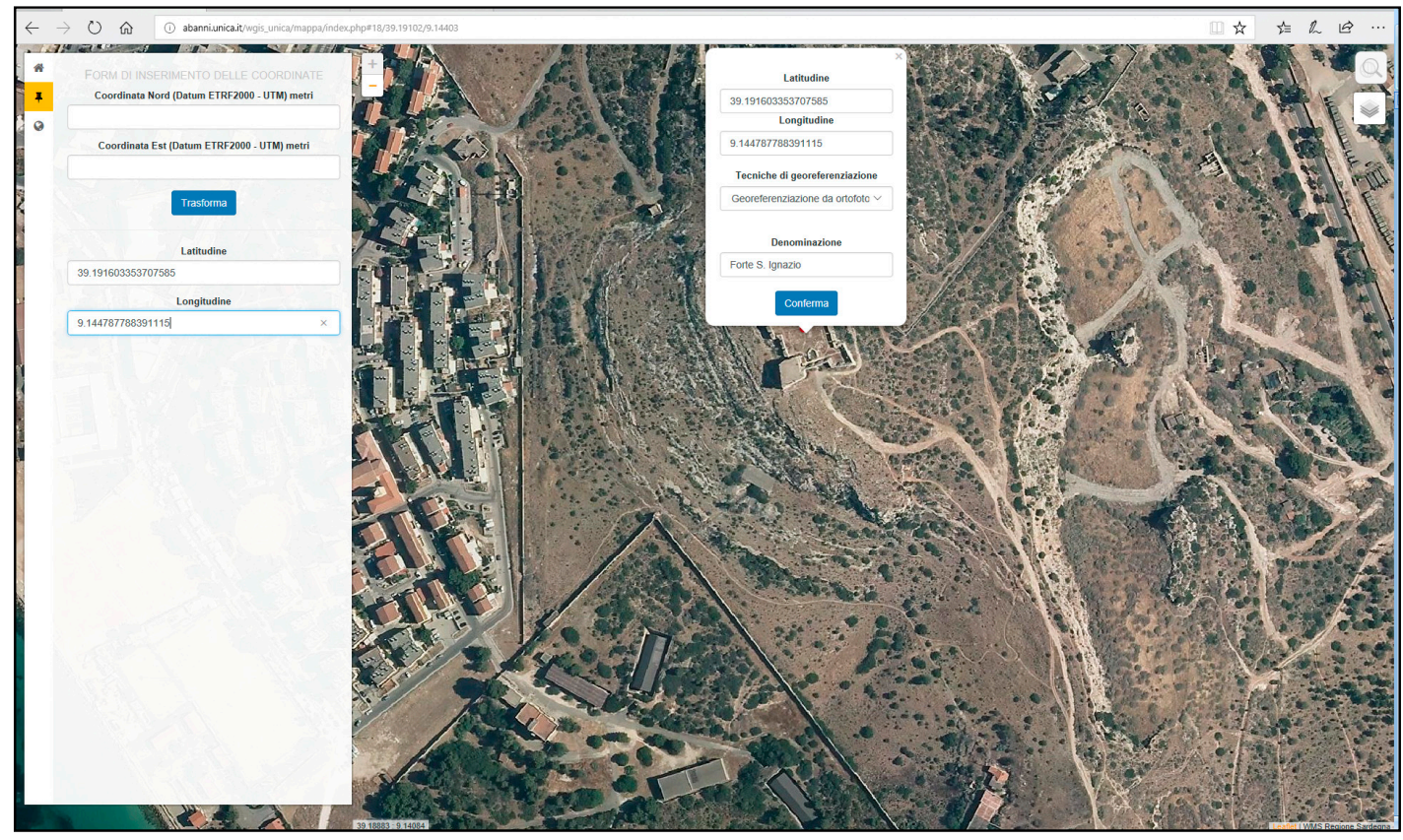

Figure 7. Coordinates input form (S. Ignazio Fort).

\subsection{GIS and 3D GIS Implementation}

A section of the research was devoted to implementing the geodatabase in Quantum GIS (QGIS), both in order to simplify the use of complex queries and the update of the data, and to work on the 3D 
aspect of the GIS. Indeed, one of the advantages of the geodatabase infrastructure we developed is being able to insert and/or update the data concurrently using different platforms (WebGIS, QGIS, or other database clients).

Quantum GIS is a popular choice for desktop GIS. In 2002, a group of volunteers started Quantum GIS as an alternative to GRASS (Geographic Resources Analysis Support System)[52], mainly for a better graphical user interface and fast spatial data viewing for Linux-based systems. It was programmed in $\mathrm{C}++$, while its extensions can be written in $\mathrm{C}++$ and Python [53]. It provides plug-ins that can be used to extend its functionalities. It supports a large range of vector and raster formats such as PostGIS, PNG, JPG, GRASS, Shapefile, DXF, WFS, WMS, GeoTiff, etc. The software can also manage tables of non-spatial data. The data can reside on the local file system, or can be retrieved and updated through a database connection or a Web service.

In this work, the geodatabase is accessed from QGIS through a database connection. The geodatabase can be both browsed and edited in the QGIS client, as shown in Figure 8. In order to connect the second level tables ("Infissi", "Strutture", and "Campione Murario") that contain no geometry data, a Python "action" uses the relationships between the architectural units table, containing the spatial component, and the related second level tables, so that the geometry can be selected starting from the first level table. This "action" was developed by Andrea Borruso and Salvatore Larosa [54].

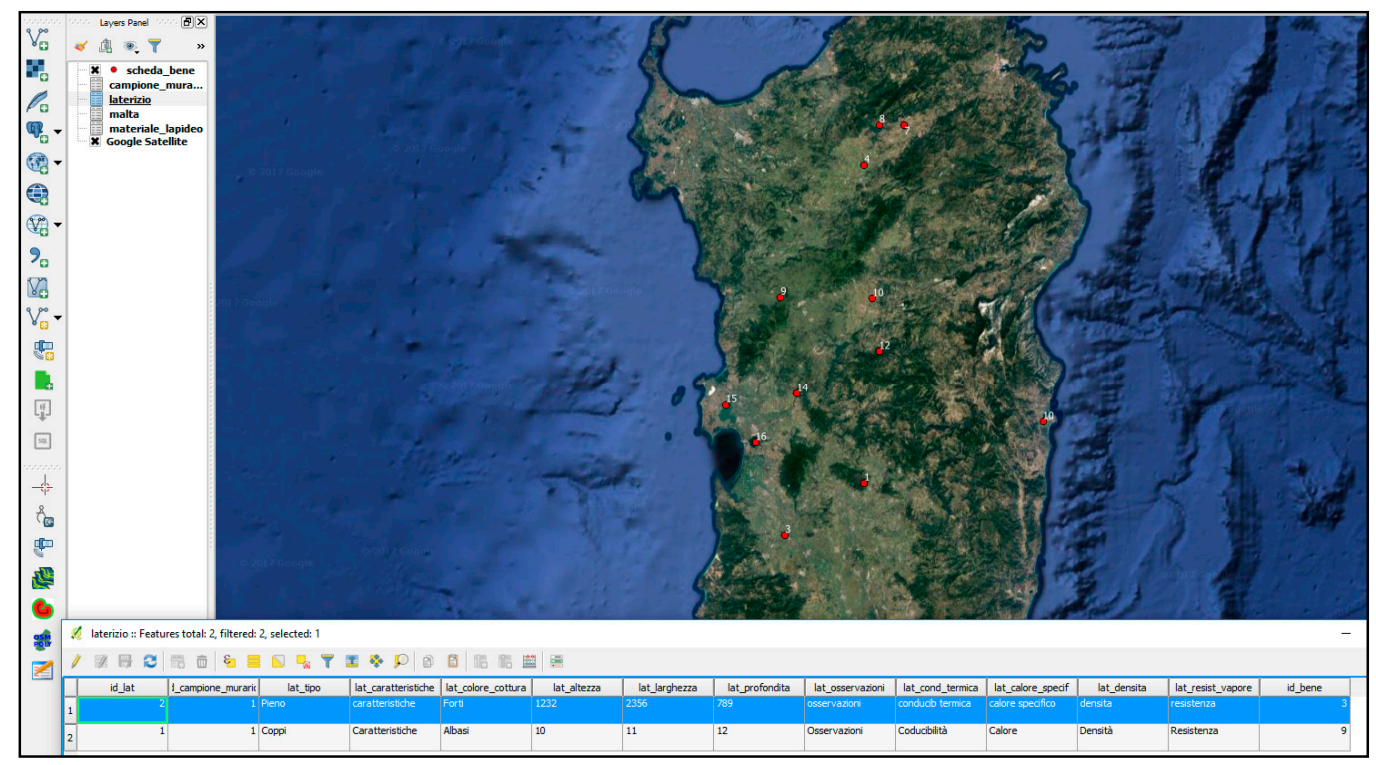

Figure 8. Quantum GIS (QGIS) project.

The final part of the development was to produce a 3D visualization of the architectural units. This was done using the Qgis2threejs plugin, which creates an interactive 3D model of the data in the QGIS project.

Qgis2threejs is based on 3D Web Graphics Library (WebGL). WebGL is one of the most important new technologies facilitating 3D visualization on the browser platform [55]. WebGL is a JavaScript API (Application Programming Interface) for the rendering of 3D graphics, and it is natively supported in most of the modern Web browsers. With WebGL, it is possible to display interactive 3D graphics if the graphics board and the related drivers on the host computer provide support for it [56].

The terrain for the 3D model was built from an orthophoto with 20-cm ground sampling distance (GSD) and a digital terrain model (DTM) with 1-m resolution. In addition, this data is from the Sardinia region geoservice $[49,50]$

The 3D model is displayed in a web browser, and includes an interface for querying the geodatabase data, as shown in Figure 9. 


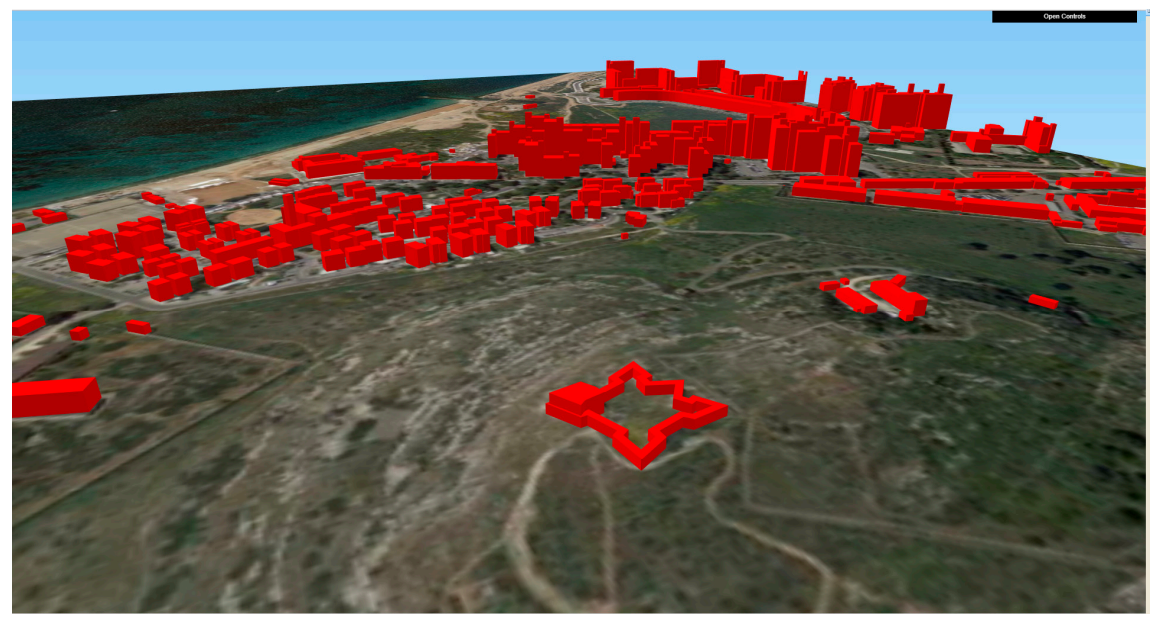

Figure 9. 3D Visualization (S. Ignazio Fort).

\section{Results}

After designing and implementing the SIS infrastructure, we started the data entry phase. The project surveyed about 500 architectural units in the entire Sardinia region (about 24,000 $\mathrm{km}^{2}$ ).

The examined architectural units are mostly of a military, religious, or civil nature. Each one was surveyed with the mode and technique most appropriate for its specific features. In most cases, it was possible to take at least one significant and representative wall sample, while in a lesser number of cases, the structures and fixtures were also surveyed.

The survey, as mentioned, used a multi-disciplinary approach involving different areas of expertise such as history and architecture, materials, restoration, construction techniques, physics, mechanics, and so on, and was performed by multiple researchers who contributed to populating the database with their data.

The data were input into the geodatabase using the WebGIS interface, that is, by locating the architectural unit on the map and filling the input forms of the geodatabase.

The WebGIS also presents some simple query operations that allow a non-expert user to query the data according to name, type, age, and location criteria. The following Figure 10 shows a query on the "Definizione" (Definition), "Cronologia" (Chronology), and "Provincia" (Province) fields.

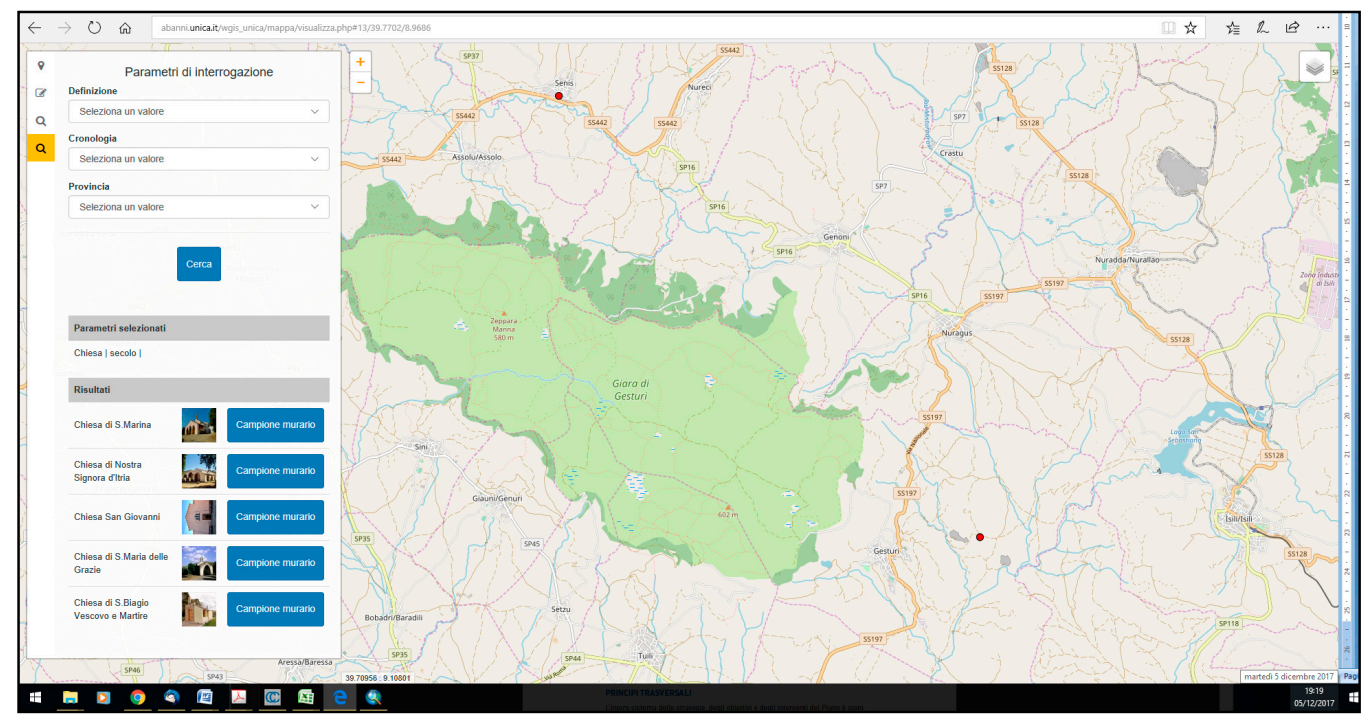

Figure 10. Query Result. 
Queries that are more complex can be performed in QGIS or by accessing the geodatabase directly. The 3D GIS was built from the "Unità Volumetrica" (Buildong-Volume Unit) class of the geodatabase of the Sardinia region. The features in this class represent a part of a building having constant ground and a top altitude, and are polygon primitives with "ground altitude" and "top altitude" attributes. Using this information, it is possible to extrude the polygons into 3D models of the architectural units. The volume units were joined to the geodatabase using the "ID_Bene" (Asset ID) field. In Figure 11, it is possible to see the Sant'Ignazio Fort (Fortino di Sant'Ignazio) in pink and its data. Due to many interdisciplinary studies carried out on the site, this defensive architecture is completely described in the SIS under several points of view. Beyond the single element, the SIS is able to represent the related military net (see Figure 12), with the possibility of comparing location, morphologies, typologies, chronologies, materials, techniques, and state of conservation. Moreover, in future developments, urban planning and design modules may be added in order to manage interventions and transformations.

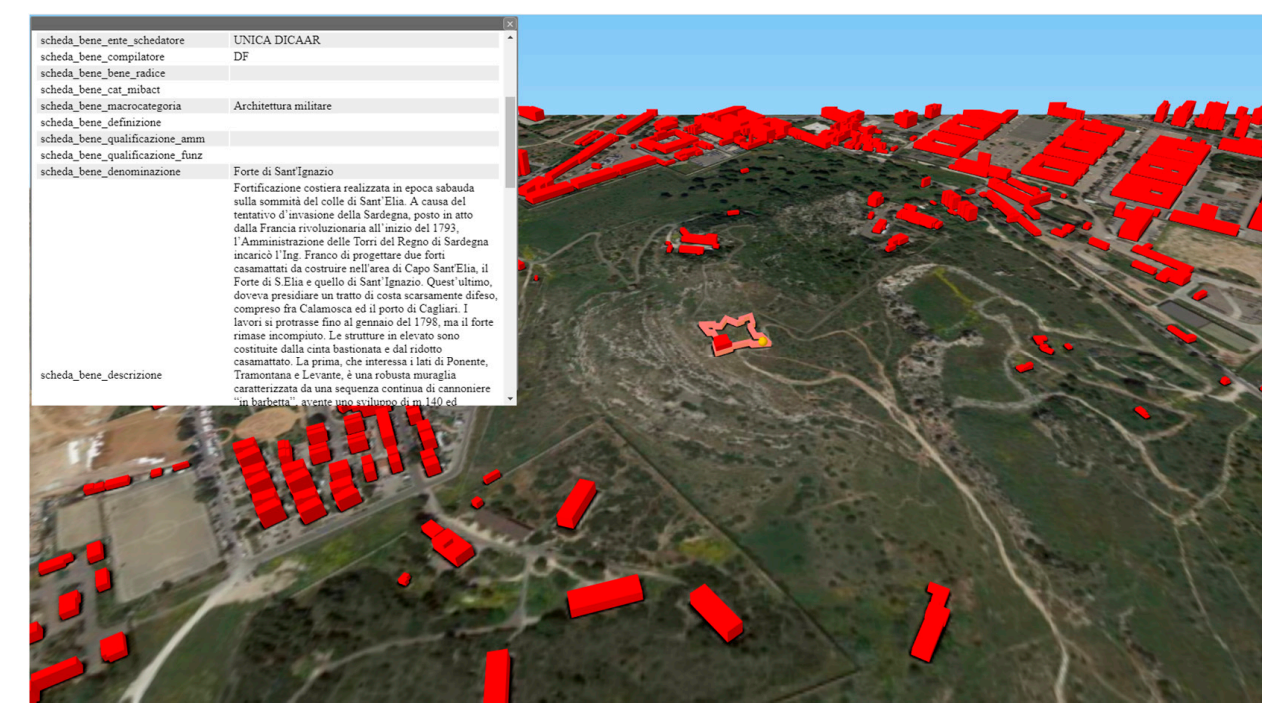

Figure 11. 3D Visualization Project (S. Ignazio Fort).

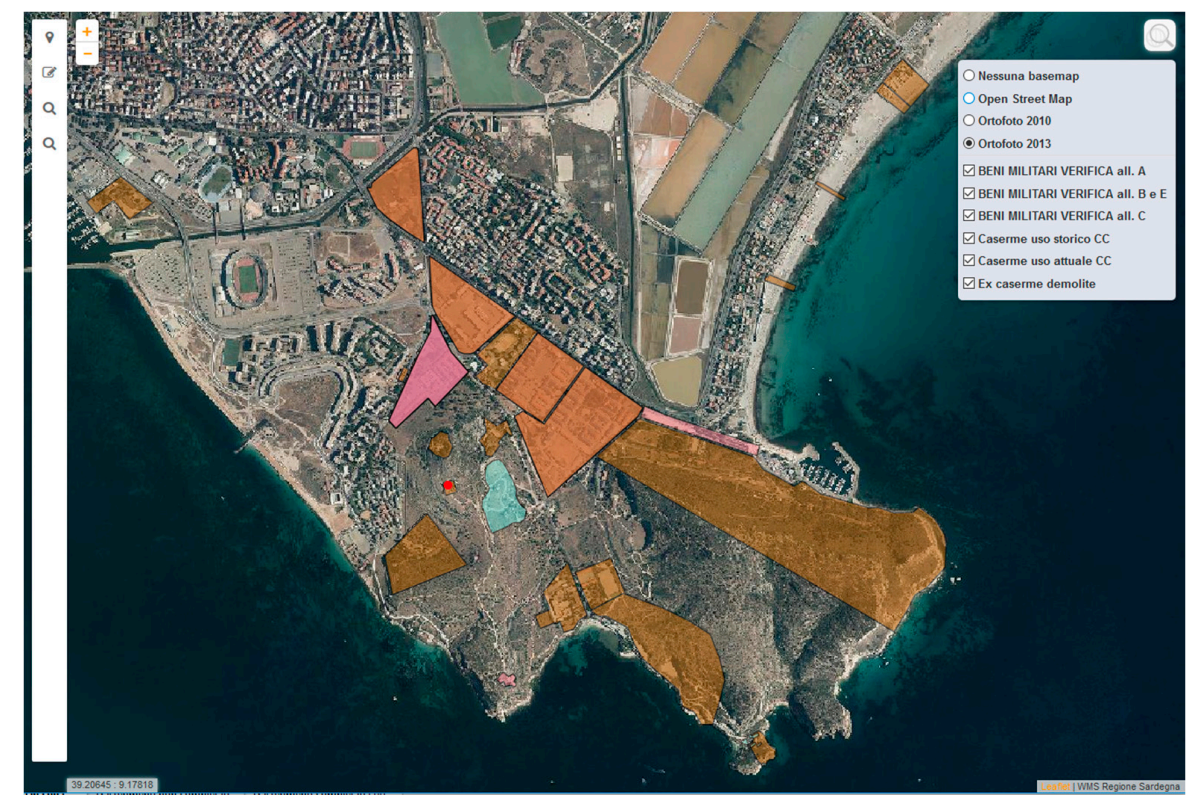

Figure 12. Areal Mapping of the Military Network in the Surrounding of the S. Ignazio Fort (red point). 


\section{Discussion}

The SIS infrastructure developed for studying the regional architectural heritage built between the 13th and 19th century, for the purpose of the study of the mensiochronology and energy efficiency aspects of the architectural heritage, consists of a geodatabase whose content can be accessed both on the Web using a WebGIS interface, and using QGIS. Its effectiveness and range of application were tested in the course of the research.

This kind of infrastructure presents several advantages. The first is the amount of data and the level of detail that the geodatabase can store, allowing both a systematic treatment of the knowledge of the historical architecture and construction techniques, and a quality of information high enough to be able to perform complex queries.

A second advantage is that the resulting infrastructure has several levels of usage, regarding both the user's expertise and the data access mode. Specifically, the data can be accessed on three levels: geodatabase, QGIS, and WebGIS. Each data access mode is related to a particular client:

- I Client: WebGIS for visualization only;

- II Client: WebGIS and QGIS for updating the data;

- III Client: Geodatabase, WebGIS, and QGIS for updating the data and performing complex queries.

Every authorization level also corresponds to an increasing level of complexity for the interface. The system is thus accessible for both expert and non-expert users. It is particularly relevant to point out that this system has been designed to fulfill different categories of users. Even if the implementation needs specific technical skills, Internet access may be possible and useful for different level of users: practitioners (engineers, architectures), the scientific community, local authorities from protective institutions, and municipalities, but also for cultural associations or simple curious people. Consequently, it follows that a quoted different method of accounting has been designed for managing these different typologies of user.

The third advantage is the interoperability of the system, which was developed using the OGC standards for geoservices and following the specifications of the Sardinia region. This allows any browser and any software compatible with the OGC specification to access the data. The availability of cultural heritage data is one of the foremost goals that both researchers and managers of the heritage have pursued in recent years. "Knowing in order to protect and preserve" is surely one of the main purposes of any agency that manages cultural heritage.

This way of structuring the SIS has thus contributed to making it a multi-purpose tool: it is clearly an archive of information, but its main function is to help the operator analyze the historical construction and materials, recognize the construction stages, and understand the historical cultural, geographical, and environmental context of the asset. In fact, going beyond the definition of a database as a mere repository of information, it is able to visualize spatially either uniform or cross-level themes, such as those related to the chronology and typology of the assets, composing scenarios that dynamically and informatively represent the changes in the historical landscape of Sardinia.

Finally, at the conclusion of the research, the WMS will be made available to the Sardinia region and the "Soprintendenza ai beni architettonici della Sardegna" (the department responsible for the architectural heritage), in order to be integrated into their geographic information systems, and thus be available to researchers of cultural heritage.

Acknowledgments: The research "Tecniche murarie tradizionali: conoscenza per la conservazione ed il miglioramento prestazionale" was financed by the Autonomous Sardinia Region within the "L. R. n. 7/2007 Promozione della ricerca Scientifica e dell'innovazione tecnologica in Sardegna" (Regional Law 7/2007-Promotion of scientific research and technological innovation in Sardinia). Principal Investigator C. Giannattasio, Reasearch Unit 1, Scientific coordinator for infrastructure SIS G. Vacca, Scientific coordinator for data structure D. R. Fiorino, working Group from the University of Cagliari, Department of Civil, Environmental Engineering and Architecture (DICAAR). 
Author Contributions: Giuseppina Vacca and Donatella Rita Fiorino conceived and designed the research; Giuseppina Vacca and Davide Pili developed the infrastructure SIS; Giuseppina Vacca wrote the paper exclude the paragraph 2.1 that Donatella Rita Fiorino wrote. Giuseppina Vacca and Donatella Rita Fiorino wrote the Results and Discussion.

Conflicts of Interest: The authors declare no conflict of interest.

\section{References}

1. Branchini, A. Tourism and Its Economic Impact in Italy: A Study of Industry Concentration and Quality of Life. Master's Thiesis, Master of Science in Urban Planning, Columbia University, New York, NY, USA, 2015.

2. Piano Strategico di Sviluppo del Turismo. Available online: http://www.pst.beniculturali.it/wp-content/ uploads/2017/05/PST_2017_IT_5mag17.pdf (accessed on 27 November 2017).

3. Rinaudo, F.; Agosto, E.; Ardissone, P. GIS and Web-GIS, commercial and open source platforms: General rules for cultural heritage documentation. Int. Arch. Photogramm. Remote Sens. Spat. Inf. Sci. 2007, 36-5/C53, 625-630.

4. Fiorino, D.R.; Pintus, V.; Vacca, G. Un WebGIS per conoscenza e tutela delle tecniche murarie tradizionali in Sardegna. Annanke 2017, 29-134.

5. Battini, C.; Vecchiattini, R. Survey and restoration: New ways of interaction. Int. Arch. Photogramm. Remote Sens. Spat. Inf. Sci. 2017, 42-5/W1, 655-662. [CrossRef]

6. Vacca, G.; Pili, D.; Fiorino, D.R.; Pintus, V. A WebGIS for the knowledge and conservation of the historical wall structures of the 13th-18th centuries. Int. Arch. Photogramm. Remote Sens. Spat. Inf. Sci. 2017, 42-5/W1, 551-556. [CrossRef]

7. Italian Sistema Informativo Generale del Catalogo SIGEC. Available online: http://www.sigecweb. beniculturali.it/it.iccd.sigec.axweb.Main/ (accessed on 13 January 2018).

8. International Commitee for DOCumentation (CIDOC). Available online: http://network.icom.museum/ cidoc/working-groups/overview/ (accessed on 13 January 2018).

9. International Council Of Museums-ICOM. Available online: http://icom.museum/ (accessed on 13 January 2018).

10. González-Perez, C.; Blanco-Rotea, R.; Mato, C.; Camiruaga, I. A Formal Language for the Description of Historical Architectural Elements. In Proceedings of the CAA2010 38th Annual Conference on Computer Applications and Quantitative Methods in Archaeology, Granada, Spain, 6-9 April 2010; Archaeopress: Oxford, UK, 2010.

11. English MIDAS Heritage. Available online: https://www.historicengland.org.uk/ (accessed on 13 January 2018).

12. Fernández Freire, C.; Del Bosque González, I.; Vicent-García, J.M.; Pérez Asensio, E.; Fraguas Bravo, A.; Uriarte González, A.; Fábrega-Álvarez, P.; Parcero-Oubiña, C. A Cultural Heritage Application Schema: Towards interoperability of Cultural Heritage Data in INSPIRE. Int. J. Spat. Data Infrastruct. Res. 2013, 8, 74-97. [CrossRef]

13. Corns, A.; Shaw, R. Cultural Heritage Spatial Data Infrastructures (SDI)-Unlocking the Potential of our Cultural Landscape Data. In Proceedings of the 30th EARSeL Symposium Remote Sensing for Science, Education, and Natural and Cultural Heritage, Paris, France, 31 May-3 June 2010; pp. 1-8.

14. Neri, A. Conoscenza e catalogazione: La cooperazione tra sistemi informativi per la gestione dei dati prima e dopo l'emergenza. Mater. Strutt. 2014, 5-6, 55-80.

15. Arnold, D.; Geser, G. EPOCH Research Agenda for the Applications of ICT to Cultural Heritage; Archaeolingua: Budapest, Hungary, 2008.

16. Crofts, N.; Doerr, M.; Gill, T.; Stead, S.; Stiff, M. Definition of the CIDOC Conceptual Reference Model; ICOM/CIDOC CRM Special Interest Group; ICOM Deutschland: Berlin, Germany, 2010.

17. Mckeague, P. Historic Environment and INSPIRE-A View from Scotland. In Progress in Cultural Heritage Preservation; Ioannides, M., Fritsch, D., Leissner, J., Davies, R., Remondino, F., Caffo, R., Eds.; Springer: Berlin/Heidelberg, Germany, 2012.

18. Peng, Z.R. An assessment framework of the development strategies of Internet GIS. Environ. Plan. Des. 1999, 26, 117-132. [CrossRef]

19. Plewe, B. GIS Online: Information Retrieval, Mapping and the Internet; OnWord Press: Santa Fe, NM, 1997. 
20. Mathiyalagana, V.; Grunwaldb, S.; Reddyb, K.R.; Bloomb, S.A. A WebGIS and geodatabase for Florida's wetlands. Comput. Electron. Agric. 2005, 47, 69-75. [CrossRef]

21. Veenendaal, B.; Brovelli, M.A.; Li, S. Review of Web Mapping: Eras, Trends and Directions. ISPRS Int. J. Geo-Inf. 2017. [CrossRef]

22. Vacca, G.; Fiorino, D.R.; Pili, D. A WebGIS for the knowledge and conservation of the historical buildings in Sardinia. Int. Arch. Photogramm. Remote Sens. Spat. Inf. Sci. 2017, 42-4/W2, 171-178. [CrossRef]

23. Meyer, E.; Grussenmeyer, P.; Perrin, J.P.; Durand, A.; Drap, P. A web information system for the management and the dissemination of Cultural Heritage data. J. Cult. Herit. 2007, 8, 396-411. [CrossRef]

24. Huang, C.H.; Chuang, T.R.; Deng, D.P.; Lee, H.M. Building GML-native web-based geographic information systems. Comput. Geosci. 2009, 35, 1802-1816. [CrossRef]

25. Pessina, V.; Meroni, F. A WebGIS tool for seismic hazard scenarios and risk analysis. Soil Dyn. Earthq. Eng. 2009, 29, 1274-1281. [CrossRef]

26. Pelcer-Vujacic, O.; Kovacevic, S.A. GIS Database of Montenegrin Katuns (Kuci Mountain and Durmitor). In Digital Heritage, Progress in Cultural Heritage: Documentation, Preservation, and Protection, Proceedings of the 6th International Conference, Euromed 2016, Nicosia, Cyprus, 31 October-5 November 2016; Springer: Berlin/Heidelberg, Germany, 2016; Part II, pp. 72-80.

27. Deidda, M.; Musa, C.; Vacca, G. A GIS of Sardinia's Coastal defense system (XVI-XVIII century). Int. Arch. Photogramm. Remote Sens. Spat. Inf. Sci. 2015, 40-4/W7, 17-22. [CrossRef]

28. Petrescu, F. The use of GIS technology in Cultural Heritage. Int. Arch. Photogramm. Remote Sens. Spat. Inf. Sci. 2007, 36-5/C53, 631-637.

29. Brovelli, M.A.; Magni, D. An archaeological WebGIS application based on MAPSERVER and POSTGIS. Int. Arch. Photogramm. Remote Sens. Spat. Inf. Sci. 2003, 34, 89-94.

30. G D’Urso, M.; Corsi, E.; Nemeti, S.; Germani, M. From excavations to Web: A GIS for archaeology. Int. Arch. Photogramm. Remote Sens. Spat. Inf. Sci. 2017, 42-5/W1, 219-226. [CrossRef]

31. Grossi, P.; Pirotti, F. GFOSS ed archeologia: L'esempio del Web GIS territoriale e di scavo di Montegrotto Terme (Padova). In Proceedings of the Atti del IX Meeting degli Utenti Italiani di GRASS-GFOSS (DICA-Dipartimento di Ingegneria Civile e Ambientale (Università di Perugia), Perugia, Italy, 20-22 Febuary 2008; pp. 113-122.

32. Deidda, M.; Pala, A.; Vacca, G. An example of a tourist location-based service (LBS) with open-source software. Appl. Geomat. 2013, 5, 73-86. [CrossRef]

33. Costamagna, E. GIS 3D: Studio e Applicazione Alla Documentazione Dei Beni Culturali. Ph.D. Thesis, Politecnico di Torino, Torino, Italy, 2012.

34. Open Geospatial Consortium. Available online: http://www.opengeospatial.org/ (accessed on 13 December 2017).

35. Regione Autonoma Della Sardegna. Available online: https://www.regione.sardegna.it/ (accessed on 13 December 2017).

36. Centro Interregionale per i Sistemi Informatici, Geografici e Statistici. Available online: http://www.cisis.it/ (accessed on 13 December 2017).

37. Inspire Infrastructure for Spatial Information in Europre. Available online: https://inspire.ec.europa.eu/ (accessed on 13 December 2017).

38. PostgreSQL. Available online: https:/ / www.postgresql.org/ (accessed on 13 January 2017).

39. PostGIS Spatial and Geographic Object for PostgreSQL. Available online: https://postgis.net/ (accessed on 13 January 2017).

40. QGIS. Available online: https://www.qgis.org/it/site/ (accessed on 13 December 2017).

41. Leaflet a Java Script Library for Interactive Maps. Available online: http://leafletjs.com/ (accessed on 20 January 2017).

42. Geoserver. Available online: http:/ / geoserver.org/ (accessed on 20 January 2017).

43. Fiorino, D.R.; Loddo, M. Innovative tools for knowledge and management of the Italian Cultural Heritage: $\mathrm{SICaR} /$ web and SIGeC/web. In Proceedings of the 12th European Architectural Envisioning Association Conference, Lodz, Poland, 23-26 September 2015; pp. 348-359.

44. Ministero Italiano Dei Beni e Delle Attività Culturali e del Turismo. Available online: http://www. beniculturali.it/mibac/export/MiBAC/index.html\#\&panel1-3 (accessed on 13 December 2017). 
45. Carta del Rischio Segretariato Genrale. Available online: http://www.cartadelrischio.it/ (accessed on 13 December 2017).

46. pgAdmin-PostgreSQL Tools. Available online: https://www.pgadmin.org/ (accessed on 13 December 2017).

47. Bootstrap the Most Popular HTML, CCS and JS Library in the World. Available online: https:/ /getbootstrap. com/ (accessed on 13 December 2017).

48. Javascript. Available online: https://www.javascript.com/ (accessed on 13 December 2017).

49. WebGIS Regione Sardegna. 2010. Available online: http://webgis.regione.sardegna.it/geoserverraster/web/ ?wicket:bookmarkablePage=:org.geoserver.web.demo.MapPreviewPage (accessed on 13 December 2017).

50. WebGIS Regione Sardegna. 2013. Available online: http:/ /webgis.regione.sardegna.it/geoserver/web/ ?wicket:bookmarkablePage=:org.geoserver.web.demo.MapPreviewPage (accessed on 13 December 2017).

51. Barbarella, M. Digital technology and geodetic infrastructures in Italian cartography. Citta' e Storia 2014, 9, 91-110.

52. GRASS GIS. Available online: https://grass.osgeo.org/ (accessed on 13 December 2017).

53. Steiniger, S.; Bocher, E. An overview on current free and open source desktop GIS developments. Int. J. Geograph. Inf. Sci. 2009, 23, 1345-1370. [CrossRef]

54. Pigrecoinfinito. Available online: https://pigrecoinfinito.wordpress.com/2017/04/16/qgis-selezionarefeature-partendo-dalle-relazioni-1m/ (accessed on 13 December 2017).

55. Wuest, R.; Eugster, H.; Nebiker, S.; Christen, M. Processing and Rendering Massive 3D Geospatial Environments Using WebGL-The Examples of Open WebGlobe and SmartMobileMapping; The Graphical Web; FHNW University of Applied Sciences and Arts Northwestern Switzerland: Zürich, Switzerland, 2012.

56. Giuliani, A.; Filipello, A.; Mandrone, G. Extreme GIS applications for 3D visualization aimed to geological and mining modeling. Ital. J. Eng. Geol. Environ. 2016, 2, 10-39. [CrossRef]

(C) 2018 by the authors. Licensee MDPI, Basel, Switzerland. This article is an open access article distributed under the terms and conditions of the Creative Commons Attribution (CC BY) license (http:/ / creativecommons.org/licenses/by/4.0/). 